\title{
Potential herbicidal effect of synthetic chalcones on the initial growth of sesame, Sesamum indicum L., and brachiaria, Urochloa decumbens (Stapf) R. D. Webster
}

\author{
Anabele Stefânia Gomes ${ }^{1,2}$, Sarah Christina Caldas Oliveira', \\ Isabele Sena Mendonça ${ }^{2}$, Cibele Carmo da Silva ${ }^{2}$, Nicholas Xavier Guiotti², \\ Lennine Rodrigues Melo ${ }^{3}$, Wender Alves Silva ${ }^{3}$ \& Fabian Borghetti ${ }^{2}$
}

\author{
University of Brasilia, Department of Botany, Laboratory of Allelopathy, CEP 70910-970, Federal District, Brazil. \\ anabelegomes@yahoo.com.br; sarahc.caldas@gmail.com \\ 2 University of Brasilia, Department of Botany, Laboratory of Thermobiology, CEP 70910-970, Brasilia, Federal District, Brazil. fborghet@unb.br \\ ${ }^{3}$ University of Brasilia, Institute of Chemistry, Laboratory of Design and Synthesis of Organic Compounds, CEP 70910-970, \\ Federal District, Brazil.wender@unb.br
}

\begin{abstract}
The search for and identification of new molecules for the development of herbicides has grown in recent decades. With the objective of developing efficient, environmentally friendly herbicides, we evaluated the phytotoxic activity of 13 synthetic chalcones on the development of sesame Sesamum indicum L. and brachiaria Urochloa decumbens (Stapf) R.D. Webster. Growth experiments were conducted at $30^{\circ} \mathrm{C}$ within a photoperiod of 12 hours. The positive control was distilled water whereas the negative control was the herbicide Glyphosate ${ }^{\circledR}$. Two chalcones $(3,13)$

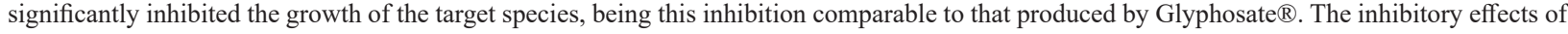
these chalcones on the growth of sesame and brachiaria deserves deeper investigation, since the methodology for their synthesis is simple and the reagents employed are of low cost, what make their large-scale production economically viable. Also, these molecules do not produce toxic residues such as those generated by synthetic herbicides.
\end{abstract}

Keywords: Brachiaria, chalcones, herbicide, sesame, weed

RESUMO - Efeito herbicida potencial de duas chalconas sintéticas no crescimento inicial de gergelim Sesamum indicum L. e brachiaria Urochloa decumbens (Stapf) R.D. Webster. A busca e identificação de novas moléculas para desenvolvimento de herbicidas tem crescido nas últimas décadas. Com o propósito de desenvolver herbicidas mais eficientes e menos tóxicos ao ambiente, avaliamos a fitotoxicidade de 13 chalconas sintéticas no desenvolvimento inicial de gergelim Sesamum indicum L. e brachiaria Urochloa decumbens (Stapf) R.D. Webster. Experimentos de crescimento inicial foram conduzidos a $30^{\circ} \mathrm{C}$ e fotoperíodo de 12 horas. Como controle utilizamos água destilada e Glifosato ${ }^{\circledR}$. Duas chalconas $(3$, 13) inibiram significativamente o crescimento de ambas as espécies, comparável ao Glifosato®. Os efeitos inibitórios destas duas chalconas abrem perspectivas para futuros estudos, visto que sua síntese é rápida e de baixo custo, tornando sua produção viável em larga escala. Além disto, não geram resíduos tóxicos como os herbicidas comerciais.

Palavras-chave: Brachiaria, chalcona, erva daninha, gergelim, herbicida

\section{INTRODUCTION}

Compounds involved in chemical interactions among organisms have gained particular interest due to the fact that they frequently present high levels of biological activity within low concentrations; in addition, they may present different, new sites of action when compared, for example, with compounds derived from chemical synthesis (Duke et al. 2000). Phytotoxic bioassays and allelopathic studies contribute both to identify and quantify the biological activity of an infinite number of compounds, in particular those obtained from plants (Hoagland \& Williams 2004). Once a compound shows relevant biological activity, its molecular structure can be utilized directly or, by means of directed structural modifications (Macías et al. 2004) can serve as template for the development of new herbicides (Oliveros-Bastidas 2008). The advantage of these new herbicides is that they usually have modes of action which differ from synthetic commercial herbicides traditionally employed in pest control (Macías et al. 2008).

Herbicides and agrochemicals based on natural products evoke interest due to the fact that they are in general minimally harmful to the environment and easily degradable by the soil biota or by physical processes (Vyvyan 2002, Huang et al. 2010). Moreover, they are frequently water-soluble, which facilitates their absorption by plants (Vyvyan 2002, Huang et al. 2010). Regarding the register of new pesticides by the USA Environmental Protection Agency (EPA) for the period of $1997-2010$, nearly $70 \%$ of the new active ingredients originated as a result of studies involving natural products, clearly showing the importance of this front in the development of new products (Cantrell et al. 2012).

Among various known secondary metabolites, flavonoids are found to be the agents presenting the 
greatest range of interactions among host plants, bacteria and pathogenic fungi (Weltring 1988), as well as among plants and symbiotic micro-organisms (Fisher \& Long 1992, Schlaman 1992), acting as photo-protectors (Li et al. 1993, Boeger \& Poulson 2005), as attractors of pollination (Forkmann 1991, Grotewold 2006), in addition to other types of interactions among organisms and the surrounding environment. About flavonoid derivatives, chalcones (1,3-diaril-2-propen-1-ones) and their derivatives are based on the structure shown in Figure 1.

Chalcones have also been the focus of investigation in studies aiming at the development of new herbicides and plant growth regulators. Chalcones were showed to inhibit the germination of seeds of Senna obtusifolia and Mimosa pudica, and such inhibition was intensified when the chalcone structure was chemically modified (Bittencourt et at. 2007). Recently, a trans-chalcone was shown to suppress the germination and initial growth of some weeds with minimal impacts on the germination and initial growth of their associated crops (Díaz-Tielas et al. 2014); the authors point out the role of chalcone as plant growth regulator and its potential use in weed management in the field.

With the aim of advancing this investigative front, the current study aims at evaluating the phytotoxic activity of 13 synthetically-obtained chalcones (Fig. 2) on the initial growth of two species: the cultivated Sesamum indicum L., commonly known as sesame, and the exotic Urochloa decumbens (Stapf) R.D. Webster, known as brachiaria (or signal grass).

\section{MATERIAL AND METHODS}

\section{Synthesis of chalcones and analogues}

Chalcones are derived from aldolic condensation between aromatic aldehydes and ketones, with overall yields ranging from 80 to $92 \%$ (fig. 2). The chalcones were characterized by ${ }^{1} \mathrm{H}$ and ${ }^{13} \mathrm{C}$ Nuclear Magnetic Resonance (NMR), which revealed characteristic signs of the desired products, as well as their respective fusion points.

\section{General procedure for the synthesis of chalcones}

The ketone $(1 \mathrm{mmol})$ was added to a solution of $\mathrm{NaOH}$ $(10 \% \mathrm{~m} / \mathrm{v})$ and ethanol $(3 \mathrm{~mL})$ and the mixture was stirred for $20 \mathrm{~min}$ under ice bath cooling. Then, the aldehyde $(1 \mathrm{mmol})$ was added and the resulting mixture was stirred overnight at room temperature. The reaction mixture was acidified with $10 \% \mathrm{HCl}$. The precipitate was collected, washed with cold

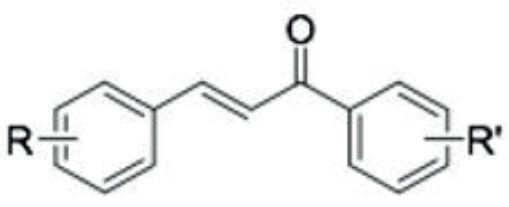

Fig. 1. General Structure of chalcones. water, dried and purified by recrystallization from $\mathrm{EtOH}$ or in chloroform. The chalcones that did not crystallize were purified by column chromatography ( $20 \%$ ethyl acetate/ hexane), (Silva et al. 2013).

\section{Synthesis of the analogue of dibenzalacetone}

Aldehyde $(2 \mathrm{mmol}$ ) was added to a solution of $\mathrm{NaOH}$ $(10 \% \mathrm{~m} / \mathrm{V})$ and ethanol $(5 \mathrm{~mL})$, and slowly added ketone $(1 \mathrm{mmol})$. The mixture was stirred for $2 \mathrm{~h}$ under ice bath cooling. The resulting solid was then filtered and washed with cold water $(3 \times 30 \mathrm{~mL})$, dried and re-crystalized in ethanol.

\section{Bioassays of phytotoxicity}

The synthesized compounds were resuspended in chloroform at concentrations of 100, 200 and $400 \mathrm{ppm}$. The solutions were then placed in Petri dishes of $5.5 \mathrm{~cm}$ in diameter lined with a filter paper, in a volume of $1.3 \mathrm{~mL}$ per dish. The dishes were then kept at laboratory conditions until the total evaporation of the solvent. After drying, the compounds were resuspended with the addition of $1.3 \mathrm{~mL}$ of distilled water in each dish.

Sesame was chosen because this species is highly sensitive to phytotoxic compounds and is routinely employed in phytotoxic and allelopathic studies (Reigosa et al. 2013); consequently, this species works well as a reliable indicator in the identification of biological activity of extracts and purified substances. Brachiaria was selected since it is a Pantropical invasive genus found in various regions within the Brazilian territory (Pivello et al. 1999), displaying vigorous growth and high tolerance to shading (Andrade et al. 2004, Martuscello et al. 2009). This genus has also been found to be highly tolerant to conditions of water stress (Melo et al. 2003) as well as to low soil fertility. In view of these facts, we believe that brachiaria is an appropriate species for testing the efficacy of bioactive compounds in rustic species resistant to environmental conditions, as is the case of invasive species that turn into weeds (Kuester et al. 2014).

The phytotoxic potential of the 13 chalcones (Fig. 2), as well as of the analogue, was tested on the initial growth of Sesamum indicum L. (sesame). For this purpose, seeds of sesame were germinated in distilled water and, once the radicle emerged, the seedlings were transferred to dishes with the compounds. Ten seeds were utilized per dish, and four dishes (replicates) per treatment. The dishes were sealed with Parafilm, and kept in a germination chamber at $30^{\circ} \mathrm{C}$ for five days. For the positive control, distilled water was utilized, whereas, as the negative control, the commercial herbicide Glyphosate ${ }^{\circledR}$ (Roundup Ready ${ }^{\circledR}$, 480 agripec) was employed, in the same concentrations as in that of the synthetic products. In the control dishes, chloroform was also added and then evaporated in an oven for subsequent addition of water or Glyphosate ${ }^{\circledR}$ solution.

After the determination of phytotoxic effects on the initial growth of sesame, the chalcones of greater activity were selected to test their effects on the initial growth of the invasive species Urochloa decumbens (Stapf) R.D. 
<smiles>CN(C)c1ccc(/C=C/C(=O)c2ccc([N+](=O)[O-])cc2)cc1</smiles><smiles>O=C(/C=C/c1ccc2c(c1)OCO2)c1ccccc1</smiles><smiles>O=C(/C=C/c1ccc2c(c1)OCO2)c1ccccc1O</smiles><smiles>O=C(/C=C/c1ccc(Cl)cc1)c1ccccc1</smiles><smiles>O=C(/C=C/c1ccccc1)/C=C/c1ccccc1</smiles><smiles>COc1ccc(C(=O)/C=C/c2ccc3c(c2)OCO3)cc1</smiles><smiles>CC(C)(C)O</smiles><smiles>O=C(/C=C/c1ccccc1)c1ccc([N+](=O)[O-])cc1</smiles><smiles>COc1ccc(/C=C/C(=O)c2ccc(-c3ccccc3)cc2)c(OC)c1</smiles>

Fig. 2. Chemical structures of synthesized chalcones and their respective yields.

Webster (brachiaria). For the purpose of the experiments, the experimental design and procedures were the same as those used in the experiments with sesame.

Upon the termination of the incubation period in the solutions, the shoot and root parts of all seedlings were measured with the aid of a digital venier caliper. Based on these measurements, the percentage of initial growth inhibition was calculated in relation to the positive control (in distilled water) as a means of comparing the effects of the compounds among themselves and with the herbicide Glyphosate $\AA$.In order to calculate the percentage of inhibition, the following formula was used:\% inhibition $=(\mathrm{XT} * 100 / \mathrm{XC})-100$.In this formula, $\mathrm{XT}$ represents the growth average for seedlings which have been treated, whereas $\mathrm{XC}$ is the growth average for the seedlings incubated in water (positive control).

The effective doses for a 50\% reduction (ED50) of the growth of the seedlings incubated in the chalcones, as

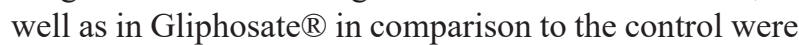
calculated according to Ritz \& Streibig (2005). Parametric data was analyzed using analysis of variance (ANOVA), with posteriori comparisons made by means of the Tukey test. Non-parametric data was analyzed using the KruskalWallis test, with posteriori comparisons made by means of the Dunn test. All the comparisons were conducted considering a probability of $5 \%$.

\section{RESULTS AND DISCUSSION}

Seed germination has been shown to be a weak parameter for testing biological activity in both phytotoxic and allelopathic studies, when compared with the initial growth of the target-species (Reigosa et al. 2013). Therefore, the seeds were previously germinated in water, and the resulting seedlings were incubated in solutions to be tested. In this study, we found two synthetic chalcones which presented a performance comparable to that of Glyphosate $^{\circledR}$ in the inhibition of the initial growth of the target species.

With the exception of compound 12, which presented an insignificant stimulus on the hypocotyl growth, each of the other products in all concentrations tested inhibited the growth of the shoot part of sesame seedlings. The products with the greatest phytotoxic effect on the shoot growth were the compounds 2, 3, 7, 9 and 13 (fig. 3).

The inhibitory effects of chalcones on the shoot growth of sesame, when compared with that of Glyphosate ${ }^{\circledR}$, may be directly related to the metabolic pathway involved. In plants, Glyphosate ${ }^{\circledR}$ is absorbed by the leaves and unprotected tissues of the meristems; this process is nonselective. In its biochemical action, Glyphosate ${ }^{\circledR}$ inhibits the activity of enolpiruvil-chiquimate-3-phosphate (EPSPS), an enzyme of the shikimic acid route, which is found in plants and micro-organisms. With this mechanism of action, Glyphosate $^{\circledR}$ interferes with the synthesis of the aromatic amino acids phenylalanine, tyrosine and tryptophan, which are the final products in the shikimic acid route and are related to the synthesis of flavonoids, coumarins and other derivatives.

The chalcones, being precursors of flavonoids, would be expected to act through a different mechanism in respect to Glyphosate $\AA$; however, in some instances, the 


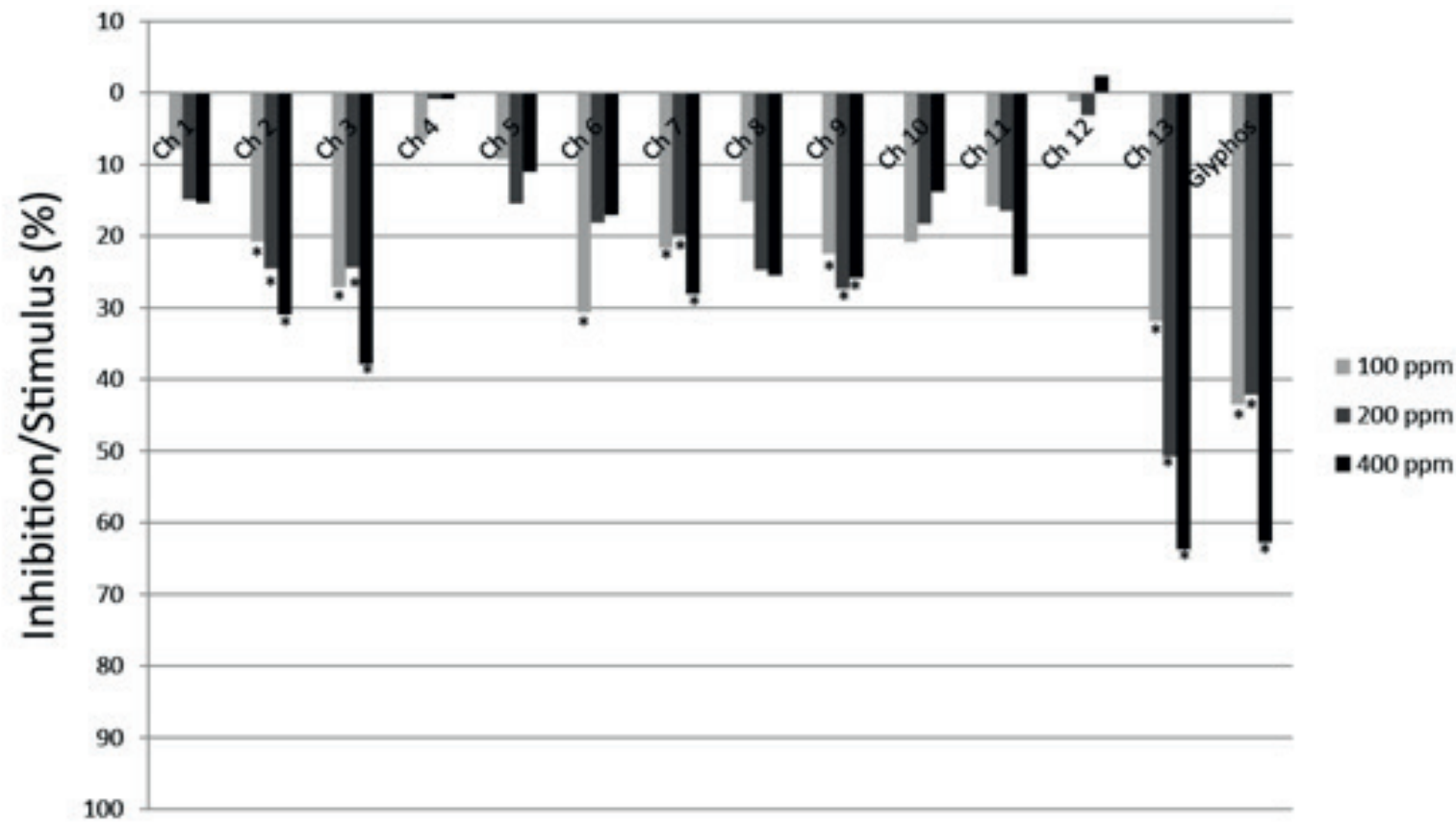

Fig. 3. Percentage of growth inhibition/stimulus of shoot parts of sesame seedlings (Sesamum indicum L.) grown for five days in water solutions containing the chalcones, or analogues, or Glyphosate ${ }^{\circledR}$, in comparison to the positive control (distilled water). The chalcones are identified in figure 2. *Indicates a significant difference in relation to the control, $\mathrm{p}<0.05$.

electronic effects of the substituents, as well as the steric hindrance effects, produce an influence that blocks the cascade sequence of events within the metabolic cycle of the plant. In this particular case, the great majority of samples which were analyzed presented a similar profile, with the exception of chalcone 13, which presented an increasing action/concentration effect; one interesting aspect is that no substituents were present in the compound, thus probably influencing, in a negative way, the synthesis of flavonoids in the metabolic branch of phenylpropanoids.

The compounds 10 and 11, as well as the compound 12 (in higher concentrations), stimulate the root growth of sesame seedlings (fig. 4). Together with the positive effect of compound 12 in stimulating the initial shoot growth of such

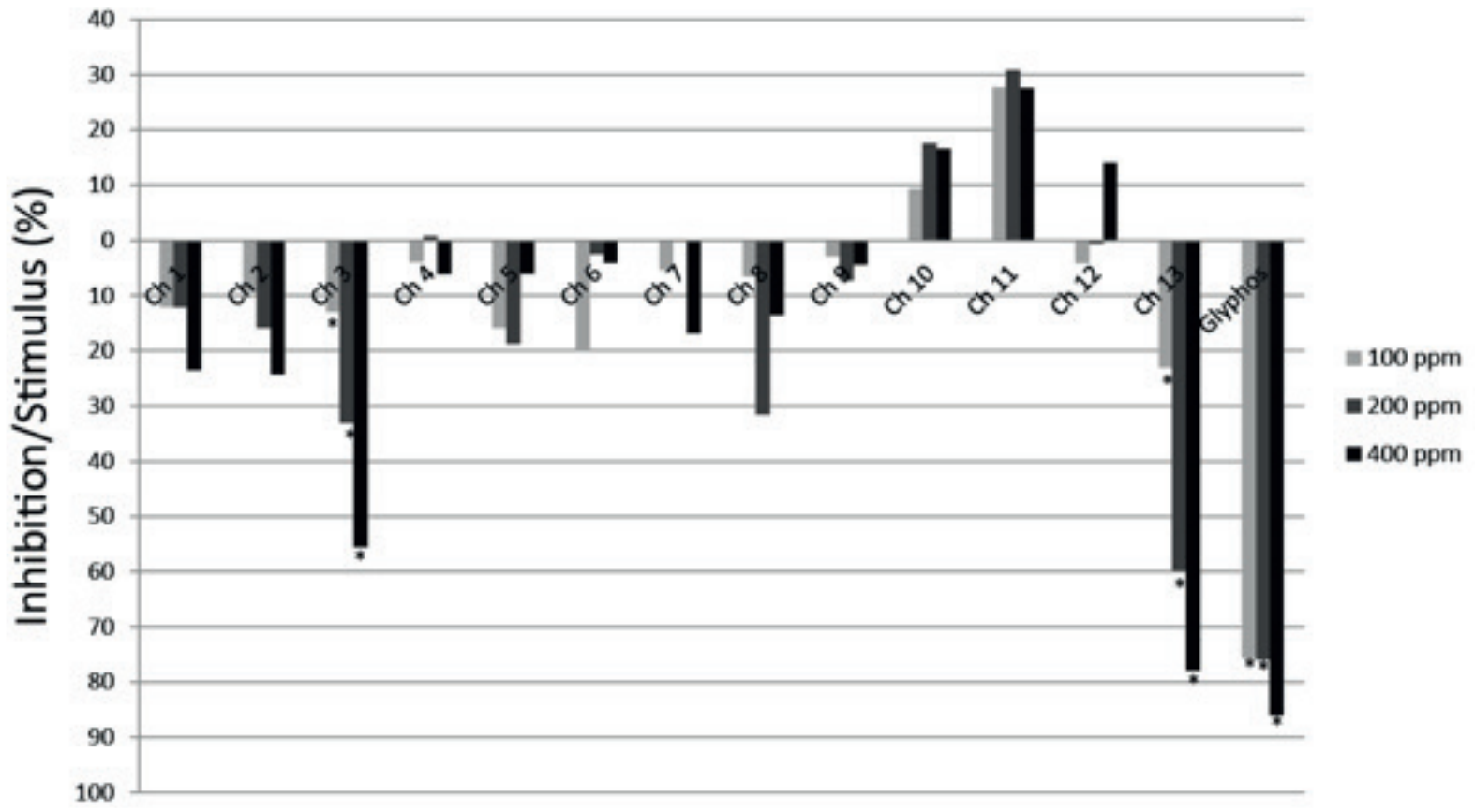

Fig. 4. Percentage of growth inhibition/stimulus of root parts of sesame seedlings (Sesamum indicum L.) grown for five days in water solutions containing the chalcones, or analogues, or Glyphosate $\AA$, in comparison to the positive control (distilled water). The chalcones are identified in figure 2. *Indicates a significant difference in relation to the control, $\mathrm{p}<0.05$. 
seedlings, the results indicate that these compounds may present common characteristics, producing a stimulating effect on initial plant growth.

One aspect to be taken into consideration is the structural similarity of compounds 10 and 11, due to the presence of the phenyl group as a substituent in the position para of the fragment derived from ketone. However, the methoxy groups $(\mathrm{OMe})$ proved to be highly important due to the fact that there was a pronounced stimulus of root growth by the compound 11 . Compound 12 , as it belongs to the nitro group $\left(\mathrm{NO}_{2}\right)$, may be acting less intensely since the electronic characteristics of this group are totally different from those of the methoxy group. Considering that most studies of phytotoxicity and allelopathy describe inhibitory effects of extracts and compounds on the germination and initial growth of the target species (Reigosa et al. 2013), it becomes particularly interesting to identify products which produce a positive effect on the germination and/or growth of plants (Santos et al. 2002, Cândido et al. 2010, Silva et al. 2011). These findings open perspectives for the development of products which focus on stimulating plant growth.

Similar to their effects on the shoot growth (fig. 3), chalcones 3 and 13 inhibited the root growth of sesame seedlings (fig. 4). Such effects reveal a consistent doseresponse response, with the chalcone 13 presenting an inhibitory effect equivalent to that of the herbicide Glyphosate ${ }^{\circledR}$. Phytotoxic effects which respond progressively to the increase in the concentration of the tested solution follow a pattern which is well documented in the literature (Gatti et al. 2004, Oliveira et al. 2004, Pina et al. 2009, Reigosa et al. 2013). In a broader analysis of the effects of chalcones on the initial growth of sesame, we found that the shoot growth was affected by a larger number of chalcones than was the root growth. These results suggest that shoot growth is more susceptible to the action of these compounds than root growth; this finding contrasts the literature on the subject, which normally describe that root growth is more susceptible to phytotoxic action than shoot growth (Reigosa et al. 2013).

In general, compounds 3 and especially 13 presented consistent results, inhibiting both shoot as well as root growth of sesame seedlings. Therefore, these two compounds were selected to test their effects on the initial growth of one particular invasive species often found in pastures due to its hardiness and tolerance to adverse conditions - the African grass Urochloa decumbens (brachiaria). This species was selected for these studies due to the fact that it has become invasive in degraded and native areas in many regions of the Brazilian ecosystems (Pivello et al. 1999). Thus, the identification of strategies which seek to mitigate the effects of this invasive species on the dynamic of native environments and to control it in cultivated areas has become relevant for the conservation and resilience of natural ecosystems.

The inhibition of shoot growth of brachiaria by chalcone 3 and, to a greater extent, by chalcone 13 (fig. 5) was less pronounced than that on the sesame growth (fig. 3), thus suggesting that the exotic species present a stronger tolerance to the effects of chemical substances than the cultivated species.

Compounds 3 and 13 significantly inhibited the root growth of brachiaria in a dose-response pattern and similar to the inhibitory effects generated by Glyphosate ${ }^{\circledR}$ (fig. 6).

The percentage of inhibition of root growth of brachiaria and sesame by compounds 3 and 13 presented overlapping values, suggesting a high level of consistency in the action of such compounds on the initial growth of a dicotyledonous species and of a monocotyledonous species. The effects generated by Glyphosate ${ }^{\circledR}$ on the shoot growth of brachiaria

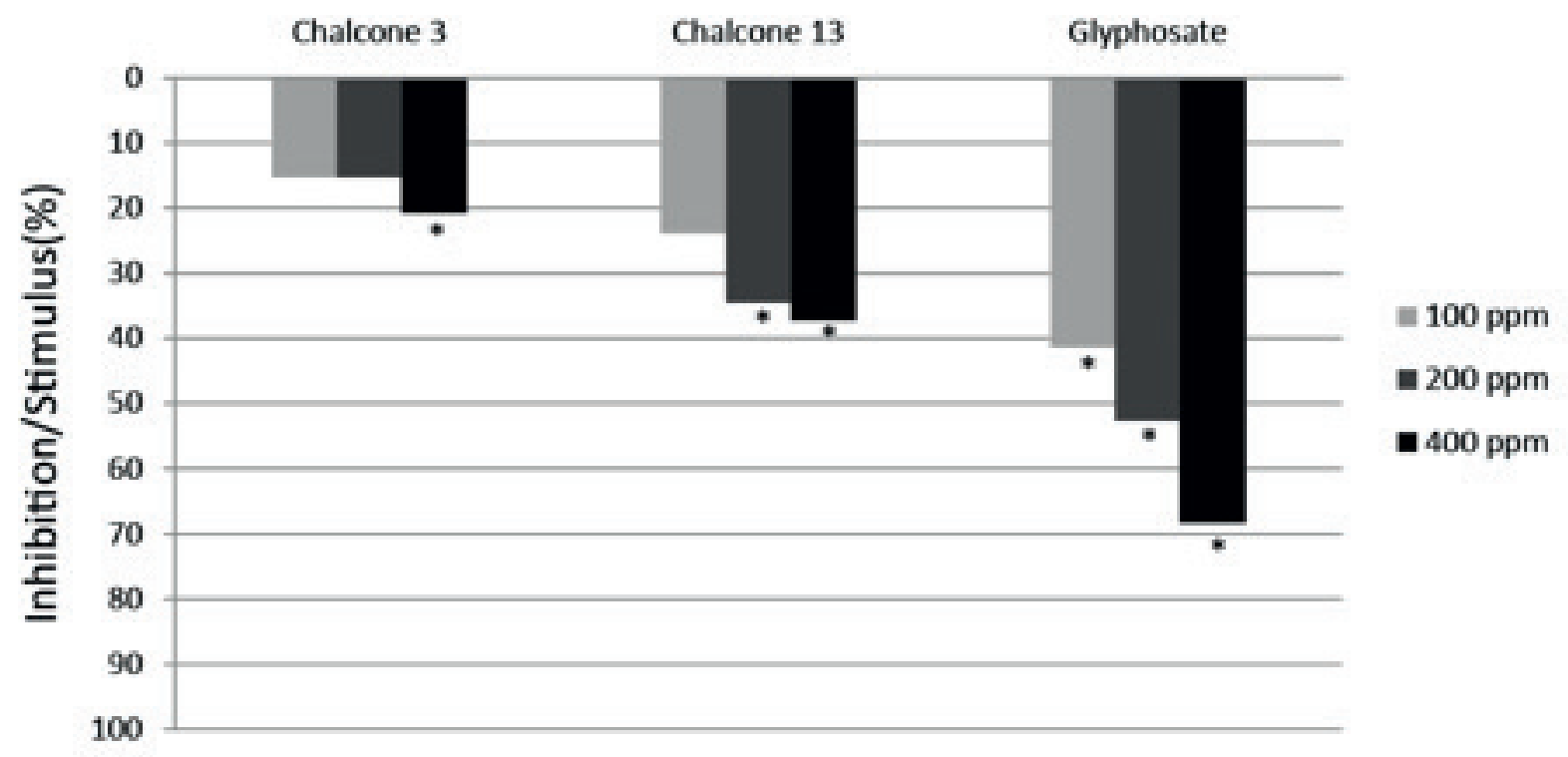

Fig. 5. Percentage of growth inhibition/stimulus of shoot parts of brachiaria seedlings [Urochloa decumbens (Stapf) R.D. Webster] grown for five

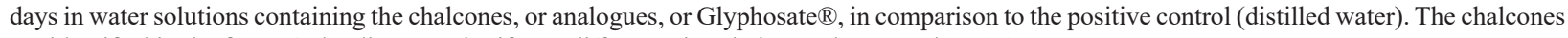
are identified in the figure 2 . *Indicates a significant difference in relation to the control, $\mathrm{p}<0.05$. 


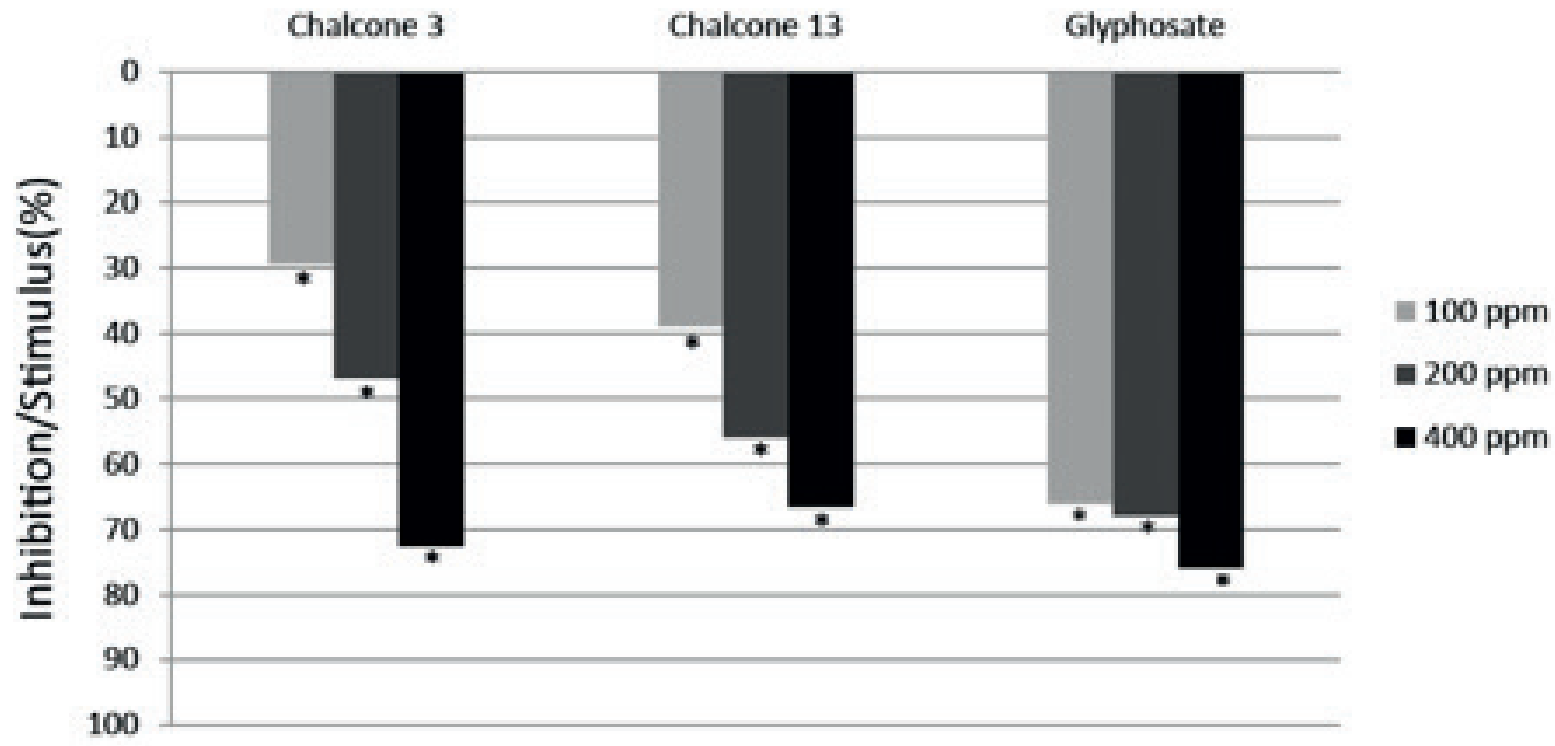

Fig. 6. Percentage of growth inhibition/stimulus of root parts of brachiaria seedlings [Urochloa decumbens (Stapf) R.D. Webster] grown for five days in water solutions containing the chalcones, or analogues, or Glyphosate ${ }^{\circ}$, in comparison to the positive control (distilled water). The chalcones are identified in the figure 2 . *Indicates a significant difference in relation to the control, $\mathrm{p}<0.05$.

(fig. 5) were similar to those generated on sesame (fig. 3); both presented an inhibition of shoot growth between 40 and $70 \%$ in relation to the growth observed in distilled water. The effects of this commercial herbicide on the root growth of brachiaria (fig. 6) were also similar to that observed for sesame (fig. 4), with inhibition percentages reaching values close and even above $70 \%$ in comparison to the control.

In contrast with the observed effects on sesame, the effects generated by chalcones 3 and 13 were more pronounced on the root than on the shoot growth of brachiaria seedlings. The effects of compounds absorbed by plants may vary depending on the plant tissue in which they act. Certain substances may provoke inhibitory effects in some tissues and stimulating effects in others within the same plant, or even of different plants depending on their mechanism of action, patterns of translocation, among other variables (Chung et al. 2001, Correia et al. 2005, Maraschin-Silva \& Aquila 2006).

The comparison of the effects generated by chalcones 3 and 13 with those generated by Glyphosate ${ }^{\circledR}$ (table 1) reveals that the commercial herbicide has a greater effect on shoot and root growth of seedlings, although the values are quite similar. We did not find statistical differences in respect to the shoot growth (100 ppm) between chalcones 3 and 13 , and in respect to the root growth by chalcone $3(400 \mathrm{ppm})$ in comparison with the effects produced by Glyphosate ${ }^{\circledR}$ (table 1). The others concentrations and treatments presented statistical differences.

The approximate effective doses (ED50) for a 50\% reduction in seedling growth indicate that root growth can be inhibited in concentration ranges which are well below those of shoot growth; in contrast, Glyphosate ${ }^{\circledR}$ inhibits the growth of brachiaria in concentration ranges below to that presented by chalcone 3 and 13 (table 2).

The present study indicates that chalcones 3 and 13 may be potential structural bases for the development of (new) substances which control plant growth; these chalcones presented significant action against both dicotyledonous and monocotyledonous species, especially against a species known for its vigorous growth and high resistance to adverse conditions. Chalcones 10 and 11 may also be of interest due to their specific action of inhibiting shoot growth while simultaneously stimulating root growth of sesame. Such findings help strengthen the need for fruitful investigation in the development of new herbicides and plant growth regulators based on simple substances of low production cost. Among the advantages of this approach is

Table 1. Average length $(\mathrm{cm})$ of the shoot and root parts of seedlings of Urochloa decumbens (Stapf) R.D. Webster (brachiaria) grown under the

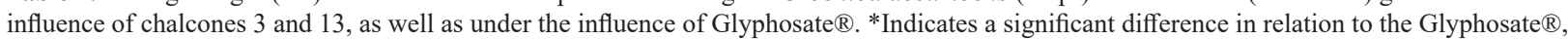
$\mathrm{p}<0.05$.

\begin{tabular}{lcccccc}
\hline Concentration & \multicolumn{3}{c}{ Shoots } & \multicolumn{3}{c}{ Roots } \\
& Chalcone 3 & Chalcone 13 & Gliphosate & Chalcone 3 & Chalcone 13 & Gliphosate \\
\hline $100 \mathrm{ppm}$ & 3.20 & 2.88 & 2.22 & $5.40^{*}$ & $4.67^{*}$ & 2.60 \\
$200 \mathrm{ppm}$ & $3.20^{*}$ & $2.48^{*}$ & 1.79 & $4.05^{*}$ & $3.36^{*}$ & 2.45 \\
$400 \mathrm{ppm}$ & $3.00^{*}$ & $2.37^{*}$ & 1.19 & 2.09 & $2.56^{*}$ & 1.84 \\
\hline
\end{tabular}


Table 2. Effective doses for a 50\% inhibition (ED50) of the growth of shoot and root parts of $U$. decumbens seedlings grown under the influence of chalcones 3 and 13 as well as under the influence of Glyphosate $\circledR$.

\begin{tabular}{lcc}
\hline \multirow{2}{*}{ Chalcone } & \multicolumn{2}{c}{ ED50 $(\mu \mathrm{M})$} \\
\hline Chalcone 3 & $204.6 \pm(32.2)$ & $24700 \pm(79700)$ \\
Chalcone 13 & $163.9 \pm(36.5)$ & $1163.6 \pm(1115.4)$ \\
Glyphosate & $15.7 \pm(31.4)$ & $162.0 \pm(38.9)$ \\
\hline
\end{tabular}

its synthetic aspect, since the reagents employed as stock material in the synthesis of chalcones is of low aggregate commercial value, making this process economically viable. In addition, they do not produce organophosphate toxic residues, which are difficult to dispose of, such as those generated by Glyphosate $\AA$.

\section{ACKNOWLEDGEMENTS}

We wish to thank the Fundação de Apoio à Pesquisa do Distrito Federal (Project number 193.000.051/2012) for funding part of this study. We also thank to Dr. A. Plausonius for reviewing the english language of the manuscript. Fabian Borghetti acknowledges CNPq for the research grant number 310916/2014-3.

\section{REFERENCES}

Andrade, C.M.S., Valentim, J.F., Carneiro, J.C. \& Vaz, F.A. 2004. Crescimento de gramíneas e leguminosas forrageiras tropicais sob sombreamento. Pesquisa Agropecuária Brasileira 39:263-270.

Bitencourt, H.R., Santos, L.S. \& Souza-Filho, A.P.S. 2007. Atividade alelopática de chalcona sintética, de seus precursores e de cetonas e aldeídos relacionados. Planta Daninha 25(4):747-753.

Boeger, M.R.T. \& Poulson, M.E. 2006. Efeitos da radiação ultravioleta-B sobre a morfologia foliar de Arabidopsis thaliana (L.) Heynh. (Brassicaceae). Acta Botanica Brasilica 20(2):329-338.

Cândido, A.C.S., Schmidt, V., Laura, V.A., Faccenda. O., Hess, S.C., Simionatto, E. \& Peres, M.T.L.P. 2010. Potencial alelopático da parte aérea de Senna occidentalis (L.) Link (Fabaceae, Caesalpinioideae): bioensaios em laboratório. Acta Botanica Brasilica 24(1):235-242.

Cantrell, C.L., Dayan, F.E. \& Duke, S.O. 2012. Natural products as sources for new pesticides. Journal of Natural Products 75(6):1231-1242.

Chung, I.M., Ahn, J.K. \& Yun, S.J. 2001. Assessment of allelopathic potential of barnyard grass (Echinochloa crus-gall) on rice (Oriza sativaL.) cultivars. Crop Protection 20(10):921-928.

Correia, N., Centurion, M. \& Alves, P. 2005. Influência de extratos aquosos de sorgo sobre a germinação e desenvolvimento de plântulas de soja. Ciência Rural 35(3):498-503.

Díaz-Tielas, C., Sotelo, T., Graña, E., Reigosa, M.J. \& Sánchez-Moreiras, A.M. 2014. Phytotoxic Potential of Trans-chalcone on Crop Plants and Model Species. Journal of Plant Growth Regulation 33(2):181-194.

Duke, S.O., Romagni, J.G. \& Dayan, F.E. 2000. Natural products as sources for new mechanisms of herbicidal action. Crop Protection 19(8):583-589.

Fischer, R.F. \& Long, S.R. 1992. Rhizobium-plant signal exchange. Nature 387:655-660.

Forkmann, G. 1991. Flavonoids as flower pigments: the formation of the natural spectrum and its extension by genetic engineering. Plant Breeding 106(1):1-26.

Gatti, A.B., Perez, S.C.J.G.A. \& Lima, M.I.S. 2004. Atividade alelopática dos extratos de Aristolochia esperanzae O. Kuntze na germinação e crescimento de Lactuca sativa L. e Raphanus sativus L. Acta Botanica Brasilica 18(3):459-472.

Grotewold, E. 2006. The genetics and biochemistry of floral pigments. Annual Review of Plant Biology 57:761-780.

Hoagland, R.E. \& Williams, R.D. 2004. Bioassays - useful tools for the study of allelopathy. In Allelopathy: Chemistry and mode of action of allelochemicals (J.C.G. Macías, J.M.G. Galindo, H.G. Molinillo \& E. Cutler, eds.). CRC Press, Boca Raton, p. 315-351.

Huang, H., Morgan, C.M., Asolkar, R.N., Marja, E., Koivunen, M.E. \& Marrone, P.G. 2010. Phytotoxicity of sarmentine isolated from long pepper (Piperlongum) fruit. Journal of Agricultural and Food Chemistry 18(58):9994-10000.

Kuester, A., Conner, J.K., Culley, T. \& Baucom, R.S. 2014. How weeds emerge: a taxonomic and trait-based examination using United States data. New Phytologist 202:1055-68.

Li, J., Ou-Lee, T.M., Raba, R., Amundson, R.G. \& Last, R.L. 1993. Arabidopsis flavonoid mutants are hypersensitive to UV-B irradiation. Plant Cell 5(2):171-179.

Macías, F.A., Molinillo, J.M.G., Chinchilla, D. \& Galindo, J.C.G. 2004. Heliannanes - a Structure-Activity Relationship (SAR) study. In Allelopathy: Chemistry and mode of action of allelochemicals (J.C.G. Macías, J.M.G. Galindo, H.G. Molinillo \& E. Cutler, eds.). CRC Press, Boca Raton, p. 103-124.

Macías, F.A., Olivero-Bastidas, A., Marín, D., Carrera, C., Chinchilla, N. \& Molinillo, J.M. 2008. Plant biocommunicators: their phytotoxicity, degradation studies and potential use as herbicide models. Phytochemistry Reviews 7(1):179-194.

Maraschin-Silva, F. \& Aquila, M.E.A. 2006. Contribuição ao estudo do potencial alelopático de espécies nativas. Revista Árvore 4(30):547555 .

Martuscello, J.A., Jank, L., Gontijo, M.M.N., Laura, V.A. \& Cunha D.N.F.V. 2009. Produção de gramíneas do gênero Brachiaria sob níveis de sombreamento. Revista Brasileira de Zootecnia 38:11831190.

Melo, S., Korndorfer, G., Korndorfer, C., Lana, R. \& Santana, D. 2003. Silicon accumulation and water deficit tolerance in Brachiaria grasses. Scientia Agricola 60(4):755-759.

Oliveira, S.C.C., Ferreira, A.G. \& Borghetti, F. 2004. Efeito alelopático de folhas de Solanum lycocarpum St.Hill (Solanaceae) na germinação e crescimento de Sesamum indicum L. (Pedaliaceae) sob diferentes temperaturas. Acta Botanica Brasilica 18(3):401-406.

Oliveros-Bastidas, A.D.J. 2008. El fenómeno alelopático. El concepto, las estrategias de estudio y su aplicación en la búsqueda de herbicidas naturales. Revista Química 7(1):1-34.

Pina, G.O., Borghetti, F., Silveira, C.E.S. \& Pereira, L.A.R. 2009. Effects of Eugenia dysenterica leaf extracts on the growth of sesame and radish. Allelopathy Journal 2:13-322.

Pivello, V.R., Shida, C.N. \& Meirelles, S.T. 1999. Alien grasses in Brazilian savannas: a threat to the biodiversity. Biodiversity and Conservation 8:1281-1294.

Reigosa, M., Gomes, A.S., Ferreira, A.G. \& Borghetti, F. 2013.Allelopathic research in Brazil. Acta Botanica Brasilica 27(4):629-646.

Ritz, C. \& Streibig, J.C. 2005. Bioassay analysis using R. Journal Statistical Software 12(5):1-22.

Santos, J.C.F, Souza, I.F., Mendes, A.N.G., Morais, A.R., Conceição, H.E.O. \& Marinho, J.T.S. 2002. Efeito de extratos de cascas de café de arroz na emergência e no crescimento de caruru-de-mancha. Pesquisa Agropecuária Brasileira 6:783-790.

Schlaman, H.R., Okker, R.J. \& Lugtenberg, B.J. 1992. Regulation of nodulation gene expression by NodD in rhizobia. Journal of Bacteriology 174(16):5177.

Silva, W.A., Andrade, C.K.Z., Napolitano, H.B., Vencato, I., Lariucci, C., Castro, M. \& Camargo, A.J. 2013. Biological and Structure-Activity Evaluation of Chalcone Derivatives against Bacteria and Fungi. Journal of Brazilian Chemical Society 24:133-144.

Silva, V.S., Cândido, A.C.S., Muller, C., Laura, V.S., Faccenda, O., Simionatto, E., Hess, S.C. \& Peres, M.T.L.P. 2011. Potencial fitotóxico de Dicranopteris flexuosa. Acta Botanica Brasilica 25(1):95-104.

Vyvyan, J.R. 2002. Allelochemicals as leads for new herbicides and agrochemicals. Tetrahedron 58:1631-1646.

Weltring, K.M., Turgeon, B.G., Yoder, O.C. \& Vanetten, H.D. 1988. Isolation of a phytoalexin-detoxification gene from the plant pathogenic fungus Nectriahaematococca by detecting its expression in Aspergillus nidulans. Gene 68(2):335-344. 